\title{
Occurrence of antibodies to Toxoplasma gondii in scavenging black vultures (Coragyps atratus) in Brazil
}

\section{Ocorrência de anticorpos anti-Toxoplasma gondii em urubus (Coragyps atratus) do Brasil}

\author{
Solange Maria GENNARI'; Tania de Freitas RASO²; Fernanda Junqueira Vaz GUIDA³ Hilda Fátima Jesus PENA; \\ Herbert Sousa SOARES ${ }^{1}$; Jitender Prakash DUBEY ${ }^{4}$
${ }^{1}$ Universidade de São Paulo, Faculdade de Medicina Veterinária e Zootecnia, Departamento de Medicina Veterinária e Saúde Animal, São Paulo - SP, Brazil
${ }^{2}$ Universidade de São Paulo, Faculdade de Medicina Veterinária e Zootecnia, Departamento de Patologia, São Paulo - SP, Brazil ${ }^{3}$ Fundação Parque Zoológico de São Paulo, São Paulo - SP, Brazil
${ }^{4}$ United States Department of Agriculture, Agricultural Research Service, Agricultural Research Center, Animal Parasitic Diseases \\ Laboratory, Beltsville - MD, USA
}

\begin{abstract}
This is the first report of Toxoplasma gondii infection in black vultures (Coragyps atratus), which are obligate scavengers found throughout the Americas. Serum samples from 121 wild black vultures caught in urban areas of the city of São Paulo, Brazil, were tested for the presence of T. gondii antibodies using the modified agglutination test (MAT; cutoff point 1:5). T. gondii antibodies were found in 16 birds (13.2\%), with titers of 1:5 (6 birds), 1:10 (8 birds), and 1:20 (2 birds).
\end{abstract}

Keywords: Coragyps atratus. Black vulture. Toxoplasma gondii. Antibodies. Brazil.

\section{Resumo}

Este é o primeiro relato de infecção por Toxoplasma gondii em urubus (Coragyps atratus) que são aves carniceiras obrigatórias, encontradas no continente americano. Amostras de soro de 121 urubus, capturados em área urbana da cidade de São Paulo, Brasil, foram testadas quanto à presença de anticorpos anti-T. gondii pelo teste de aglutinação modificada (MAT, ponto de corte de 1:5). Anticorpos foram encontrados em 16 (13,2\%) aves com títulos de 1:5 (6 aves), 1:10 (8 aves) e 1:20 (2 aves).

Palavras-chave: Coragyps atratus. Urubus. Toxoplasma gondii. Anticorpos. Brasil.

Correspondence to:

Solange Maria Gennari

Faculdade de Medicina Veterinária e Zootecnia da

Universidade de São Paulo, Departamento de Medicina

Veterinária Preventiva e Saúde Animal

Av. Prof. Dr. Orlando Marques de Paiva, 87 - Cidade Universitária

CEP 05508-270, São Paulo, SP, Brazil

e-mail: sgennari@usp.br

Received: 24/03/2017

Approved: 06/06/2017

Black vultures, Coragyps atratus (2012) are birds that belong to the order Cathartiformes, family Cathartidae (DEL HOYO et al., 2014). The population size is extremely large and they can be found throughout the Americas (CORAGYPS ATRATUS, 2012).

In urban areas large groups of black vultures can be easily observed in regions of waste dumps and landfills, or in environments with animal carcasses (FERGUSONLEES; CHRISTIE, 2001; SICK, 2001; SIGRIST, 2006). Vultures feed almost exclusively on decomposing carcasses. Little is known about parasitic infections in vultures.

Toxoplasma gondii is a coccidian parasite that infects humans and other animals worldwide. The parasite can cause mortality and subclinical infection among many animal species, including birds (DUBEY, 2010). Although there have been reports of $T$. gondii infection in scavenging birds (ARENE, 1999; SALANT et al., 2013; STRAUB et al., 2015), we are unaware of any reports on T. gondii infection in black vultures. The present study aimed at determining the presence of $T$. gondii antibodies in wild black vultures (Coragyps atratus) in Brazil.

This study followed the ethical principles for animal research of the Brazilian College of Animal Experimentation 
and was approved by the Ethics Committee for Animal Research of the School of Veterinary Medicine of University of São Paulo (protocol no. 2865/2013). A permit for catching black vultures was obtained from Chico Mendes Institute for Biodiversity Conservation, Brazil (SISBIO 37849-1).

Blood samples were collected from 121 adult wild black vultures of both sexes, which were caught in urban areas of the city of São Paulo (SP), Brazil. Capture and sampling were carried out between May and August 2014.

The vultures were caught using traps that had small wire mesh openings and two compartments. They entered by passing through funnel doors in the first compartment and were trapped in the second compartment. They were then restrained manually for sample collection. Blood samples $(2 \mathrm{~mL})$ were obtained from the right medial metatarsal vein. These samples were then centrifuged and the resultant serum was stored at $-20^{\circ} \mathrm{C}$ until tested.

Four primary feathers were cut from the right wing of each bird, thus avoiding double sampling. Vultures are not sexually dimorphic (the males and females appear the same in size and color), and thus we would not have been able to determine the gender of each bird without additional testing.

The serum samples were tested for the presence of antibodies to $T$. gondii using the modified agglutination test (MAT) as described by Dubey and Desmonts (1987). They were primarily screened at a dilution of $1: 5$ and the positive samples were two-fold serially diluted. Positive and negative control chicken sera were used in each test.

Antibodies to T. gondii were detected in 16 (13.2\%) of the 121 vultures, with titers of 1:5 (6 birds), 1:10 (8 birds), and 1:20 (2 birds). None of the birds sampled in this investigation manifested any illness.

The MAT used in the present study is considered specific for T. gondii infection and was recently evaluated for efficacy of diagnosing T. gondii antibodies in naturally

\section{References}

ARENE, F. O. I. Seroprevalence of Toxoplasma gondii in vultures (Pseudogyps africanus) from eastern Nigeria. Acta Parasitologica, v. 44, n. 1, p. 79-80, 1999.

CORAGYPS ATRATUS. The IUCN Red List of Threatened Species, 2012. doi: 10.2305/IUCN.UK.20121.RLTS.T22697624A40293403.en. infected birds, using isolation of viable parasites as the gold standard (DUBEY et al., 2016). Viable T. gondii were isolated from 16 out of 105 chickens with a MAT titer of $1: 5$, and none of the 23 cats that were fed with hearts pooled from 802 free-range seronegative chickens (MAT < 1:5) excreted oocysts, thus indicating that the chickens were not infected with $T$. gondii. Therefore, in the present study, the serum samples from the vultures were screened at a dilution of 1:5. We did not know whether the serological results of the MAT in chicken could be applied to vultures. Therefore, we presented all the titers found in the present study of vulture serum.

Although no information relating to $T$. gondii infection in black vultures was available, we found four reports on seroprevalence in other species of scavenging birds. Using MAT at a cutoff of 1:25, Arene (1999), in Nigeria, found seropositivity in $64.8 \%$ of 240 white-backed vultures ( $G y p s$ africanus). In Israel, Salant et al. (2013), also with MAT $\geq 1: 25$, detected seropositivity in 40 (39.6\%) out of 101 griffon vultures (Gyps fulvus). Regarding another vulture species, the turkey vulture (Cathartes aura) in the USA, one of the two birds examined presented T. gondii antibodies when tested using the indirect hemagglutination test (FRANTI et al., 1975). Also studying the same species of vultures, in California Straub et al. (2015) found $11 \%$ positivity (7/66 using a commercial agglutination test (cutoff $\geq 32$ ).

It is important to note that the vultures in the present study live in an urban area of a large city and have wide and varied sources of food, unlike other vultures living in rural areas or in wild environments. Further studies are needed to attempt isolation of viable T. gondii from vultures.

\section{Acknowledgements}

The authors wish to thank the Fundação Parque Zoológico de São Paulo, Brazil, for its collaboration in this research. Solange Maria Gennari holds a fellowship from CNPq (Brazil).

DEL HOYO, J.; COLLAR, N. J.; CHRISTIE, D. A.; ELLIOTT, A.; FISHPOOL, L. D. C. HBW and birdlife international illustrated checklist of the birds of the world. Barcelona: Lynx Edicions; Cambridge, CA: BirdLife International, 2014. v. 1.

DUBEY, J. P. Toxoplasmosis of animal and humans. 2. ed. Boca Raton: CRC Press, 2010. 
DUBEY, J. P.; DESMONTS, G. Serological responses of equids fed Toxoplasma gondii oocysts. Equine Veterinary Journal, v. 19, n. 4, p. 337-339, 1987. doi: 10.1111/j.20423306.1987.tb01426.x.

DUBEY, J. P.; LAURIN, E.; KWOK, O. C. H. Validation of the modified agglutination test for detection of Toxoplasma gondii in free-range chickens by using cat and mouse bioassay. Parasitology, v. 143, n. 3, p. 314-319, 2016. doi: 10.1017/S0031182015001316.

FERGUSON-LEES, J.; CHRISTIE, D. A. Order ciconiiformes, family Cathartidae (New world vultures). In: FERGUSON-LEES, J.; CHRISTIE, D. A. Raptors of the World. Boston: Houghton Mifflin Company, 2001. p. 305-315.

FRANTI, C. E.; CONNOLLY, G. E.; RIEMANN, H. P.; BEHYMER, D. E.; RUPPANNER, R.; WILLADSEN, C. M.; LONGHURST, W. A survey for Toxoplasma gondii antibodies in deer and other wildlife on a sheep range. Journal of the American Veterinary Medical Association, v. 167, n. 7, p. 565-568, 1975.

SALANT, H.; HAMBURGER, J.; KING, R.; BANETH, G. Toxoplasma gondii prevalence in Israeli crows and Griffon vultures. Veterinary Parasitology, v. 191, n. 1-2, p. 23-28, 2013. doi: 10.1016/j.vetpar.2012.07.029.

SICK, H. Ornitologia brasileira. 2. ed. Rio de Janeiro: Nova Fronteira, 2001.

SIGRIST, T. Aves do Brasil: uma visão artística. São Paulo: Avis Brasilis, 2006.

STRAUB, M. H.; KELLY, T. R.; RIDEOUT, B. A.; ENG, C.; WYNNE, J.; BRAUN, J.; JOHNSON, C. K. Seroepidemiologic survey of potential pathogens in obligate and facultative scavenging avian species in California. PLoS One, v. 10, 2015. doi: 10.1371/journal.pone.0143018. 